\title{
RELATIONSHIP BETWEEN PSYCHOSOCIAL WORKING CONDITIONS AND THE ENTREPRENEURIAL INTENTIONS OF STUDENTS
}

\begin{abstract}
The present article describes research findings about students' entrepreneurial intentions, defined as an intention of starting one's own business. The main purpose of the research was to identify the relation between the assessment of entrepreneurial work and entrepreneurial intentions. In addition, the research assessed the psychosocial risks related to working as an entrepreneur and examined key individual and socio-demographic variables related to attitudes regarding entrepreneurial work. The results showed that participants believe that entrepreneurial work has a high level of psychosocial risk. The results also showed that there are some weak yet statistically significant correlations between the index of entrepreneurial psychosocial working conditions and the level of intention of starting one's own business and the probability of becoming an entrepreneur within five years.
\end{abstract}

Keywords: business, entrepreneurial intentions, entrepreneurship, psychosocial working conditions.

\section{INTRODUCTION}

The process of starting own business is considered as an intentional activity preceded by making a decision about starting an entrepreneur's career (Krueger, Reilly, Carsrud, 2000), therefore forming an entrepreneurial intention, considered as an intention to start own business. The literature shows a deep consideration over the widely-considered intentions, in particular the factors that shape them (Krueger, Reilly, Carsrud, 2000; Luthje, Franke, 2004; Sieger, Fueglistaller, Zellweger, 2011; Gasse, Tremblay, 2011; Solesvik, 2013). It is a reason for identifying not only various sets of determinants, but also their effect on forming an intention to become an entrepreneur. Among the factors studied, it is worth paying attention to the way the entrepreneur's work is perceived. It can be assumed that the perception of its characteristics and conditions is an additional element of assessing the attractiveness of the entrepreneur's work, whose influence on the entrepreneurial intentions was also analyzed (Linan, Fayolle, 2015; Barba-Sanchez, Atienza-Sahuquillo,

\footnotetext{
${ }^{1}$ Anna Walczyna, PhD, Department of Strategy and Business Planning, Faculty of Management, Lublin University of Technology, ul. Nadbystrzycka 38, 20-618 Lublin; e-mail: a.walczyna@pollub.pl (corresponding author). ORCID: 0000-0002-9193-4612.

2 Anna Arent, PhD, Department of Management, Faculty of Management, Lublin University of Technology, ul. Nadbystrzycka 38, 20-618 Lublin; e-mail: a.arent@ pollub.pl. ORCID: 0000-0002$-5655-6353$.
} 
2017). The research findings also showed that "starting, and running one's own business is connected with high risk and stress and requires a lot of time and funds" (Piróg, 2014). The assessment of characteristics and conditions related to the entrepreneur's work may be connected with a risk related to choosing a certain activity in the labor market, which always leads to the occurrence of certain profits, but also to a wide range of potential losses or negative consequences (Mills, Pawson, 2006). The last aspect is of special importance in case of starting a business activity, as the potential losses affect not only the entrepreneur as an individual, but also the employees and the environment in which the company operates. Therefore the assumption that the risk of being an entrepreneur is high may result in insufficient formation of the entrepreneurial intentions, and consequently the resignation from this way of developing a professional career.

\section{PSYCHOSOCIAL RISK, STRESS AND WORK REQUIREMENTS}

One of the types risk that is currently deeply analyzed in the literature is the psychosocial risk associated with working conditions. In broad terms, adopted in the PRIMA-EF project, "a psychosocial risk connected with work concerns those work designing and managing aspects, and also social and organizational contexts of work, that can cause mental or physical injuries" (Leka, Griffiths, Cox, 2009: 11). The characteristics of work environment can also include the context of work, therefore the aspects such as the organizational culture, the roles inside the organization, career development, decisions and control range or the interpersonal relations at work, work subject, and in particular: work conditions, equipment, undertaken tasks' conditions, workload, tempo of work or time distribution (Cox, Griffiths, Rial-Gonzalez, 2006).

The connection between psychosocial working conditions and psychosocial risk can be considered as a stress mechanism (Widerszal-Bazyl, 2009). The significant models that can explain the formation of stress at work are the following: job demands-control (JD-C) Karaska, demands-control-support (DCS) Johnson and Hall, effort-reward imbalance (ERI) Siegrista, and also job-demand resources (JD-R) Demerouti and Bakker (Derbis, Baka, 2011; Potocka, Waszkowska, 2013; Schaufeli, Taris, 2014). All of them consider demands as a significant element of the stress formation process ${ }^{3}$. Assessment of the level of demands is also an essential element of tools prepared to measure the stress level at work. The following can be enumerated as the examples ${ }^{4}$ : Psychosocial Job Conditions Survey (hereinafter referred to as PWP), the ERI Survey in the Polish adaptation by Widerszal-Bazyl and Radkiewicz - the demands are listed therein in scale of Work Involvement (Effort), Job Features Survey (hereinafter referred to as KOCP) and Individual Job Rating Survey (hereinafter referred to as KSOP) created by Dudek and his coworkers, Short Scale for Stress Measuring at the workplace (Polish adaptation - Dudek and Hauk), Workplace Stress Measuring Survey, Psychosocial Risk Scale Survey by Merecz and her coworkers, or even Copenhagen Psychosocial Survey in the Polish adaptation by Widerszal-Bazyl (Cieślak, Widerszal-Bazyl, 2000; Dudek, Waszkowska, Merecz, Hanke, 2004; Potocka, 2012; Mościcka-Teske, Potocka, 2014; Orlak, Gołuch, Chmielewski, 2014; Fila, 2016;

\footnotetext{
${ }^{3}$ Considering the individual perception of job demands, it can be connected both to demands challenges and obstacles (Mockałło, Widerszal-Bazyl, 2018).

${ }^{4}$ Research described in the article was conducted in Poland, with use of a tool written in Polish, therefore considering stress-measuring tools, only the Polish tools or the Polish-adapted ones were mentioned.
} 
Widerszal-Bazyl, 2017). The demands - both real and abstract - can therefore be of great importance when making a decision about the career path as high requirements can potentially lift the psychosocial risk. According to the Job Demand resources model, that kind of risk can be reduced with suitable resources - both the individual ones and those at the workplace. However, to achieve that, an individual has to possess such resources and the knowledge on how to use them (Potocka, Waszkowska, 2013; Kaczmarska, Curyło-Sikora, 2016).

Both the manager's and the entrepreneur's jobs are closely related in terms of being considered as stress-causing and connected with numerous psychosocial risks, and therefore burdened with high psychosocial risk (Basińska, 2005; Żemigała, 2007; Biegańska, 2008, Wróblewska, 2013; Syper-Jędrzejak, 2014). As a consequence, this may be a potentially dissuasive factor in choosing such career path, particularly considering the individuals entering the labor market, including the university graduates (Arent, Walczyna, 2014a; Walczyna, Arent, 2014).

\section{METHODOLOGY}

The research presented herein is a part of a bigger project concerning the conditions of the entrepreneurial intentions among the Polish university students. The research tool used therein had been verified and adjusted during the previous pilot research (Arent, Walczyna, 2014a; Arent, Walczyna, 2014b; Walczyna, Arent, 2014). The presented results were developed based on the second part of the project, which was created on the grounds of the "W" scale, used in the Psychosocial Job Conditions Survey (Cieślak, Widerszal-Bazyl, 2000). The assessment of demands that are connected with managing one's business was performed based on 17 items (Cronbach's alpha value - 0.872). The responses were scaled using the five point Likert scale showing that the respondents "Strongly agree" (5) to "Strongly disagree" (1) with a given statement in relation to their business activity.

The group of students surveyed was differentiated in terms of the major (Management vs technical studies), but also other sociodemographic factors, such as gender, age, citizenship, place of residence, university, grade, work experience or entrepreneurial traditions. It was stated (Arent, Walczyna, 2018) that all of them could correlate with both entrepreneurial intentions (the main aim of the research) and the assessment of demands connected with the entrepreneur's work.

The following were used as the leading research questions:

1. How the respondents assess the psychosocial risk connected with the entrepreneur's work?

2. What variables (individual, socio-demographic) differentiate the perception of the entrepreneur's work?

3. Does the correlation between the psychosocial risk awareness and the students' business intentions exist?

4. What is the correlation between the assessment of the psychosocial entrepreneur's work conditions and the entrepreneurial intentions of the students in short and long periods of time?

The research was conducted in the years 2016-2017 on a sample of 729 students (727 questionnaires were qualified for the final analysis). During the first phase the students of Management from three universities based in Lublin: Lublin University of Technology (PL), Maria Curie Skłodowska University (UMCS) and The John Paul II Catholic 
University of Lublin (KUL) took part in the survey. During the second phase, the students of technical majors were surveyed. The research sample's characteristics are presented in Table 1.

Table 1. The research sample's characteristics

\begin{tabular}{|c|c|}
\hline Variable & Data \\
\hline Gender & Female $-59.3 \%$ Male $-40.7 \%$ \\
\hline Age & $\begin{array}{l}22 \text { y.o. and less }-31.5 \% ; 23-25 \text { y.o. }-64.1 \% ; 26 \text { y.o. } \\
\text { and more }-4.4 \%\end{array}$ \\
\hline Citizenship & Polish $-93.4 \% ;$ other $-6.6 \%$ \\
\hline Place of birth & $\begin{array}{l}\text { Village }-46.9 \% \text {; town (less than } 200 \mathrm{k} \text { citizens) - } \\
27.0 \% \text {; city (more than } 200 \mathrm{k} \text { citizens) }-26.1 \%\end{array}$ \\
\hline Business experience in family & Yes $-34.8 \%$; no $-65.2 \%$ \\
\hline Job status during survey* & $\begin{array}{l}\text { Contract of employment }-7.6 \% \text {; civil law agreement } \\
-25.9 \% \text {; own business }-1.6 \% \text {; unemployed }-64.9 \%\end{array}$ \\
\hline University & PL-71.1\%; UMCS - 19.1\%; KUL - 9.8\% \\
\hline Grade & Undergraduate $-44.7 \%$; Graduate program $-55.3 \%$ \\
\hline Major & Management $-48.8 \%$; technical studies $-51.2 \%$ \\
\hline
\end{tabular}

* The three first categories were combined in further calculations presented herein

Source: own study based on the survey results.

\section{RESULTS}

Basic descriptive statistics for the specific characteristics of the entrepreneur's work are listed in Table 2.

The obtained data indicate that the work of the entrepreneur is perceived as being associated with high requirements that, in the absence of resources or the skills to use them properly, can generate high levels of stress and other associated risks. This applies mainly to the belief that negligence of one's responsibilities can lead to serious consequences, a sense of responsibility for employees, the need for numerous social contacts, as well as the responsibility for fixed assets. The obtained means vary between 4.18 and 4.29 and the mode is equal to 5. Similar means (from 4.15 to 4.23 ) but with the mode of 4 were obtained for the statements that the entrepreneur's work demands high concentration, making financial decisions connected with the business' functioning, cooperation with authorities and other public institutions, solving complicated problems and planning actions for a long time ahead. The lowest marks were obtained by the statement about demand for breaking rules for the sake of maintaining effectiveness (mean 2.76, mode 3 ).

The U Mann-Whitney and Kruskall-Wallis tests were used to check which variables differentiate the perception of the individual work's characteristics that make up for the psychosocial working conditions of the entrepreneur. Table 3 shows the significance level $\mathrm{p}$ of the observed differences. 
Relationship between psychosocial working conditions ...

Table 2. Assessment of the Entrepreneur's Psychosocial Working Conditions

\begin{tabular}{|c|c|c|c|c|c|c|}
\hline \multirow{2}{*}{$\begin{array}{c}\text { Characte- } \\
\text { ristic's } \\
\text { number }\end{array}$} & \multirow[b]{2}{*}{ Specification } & \multicolumn{5}{|c|}{ Descriptive statistics } \\
\hline & & Mean & Valids & Mode & \begin{tabular}{|c|c|}
$\begin{array}{c}\text { Mode } \\
\text { size }\end{array}$ \\
\end{tabular} & $\begin{array}{l}\text { Standard } \\
\text { deviation }\end{array}$ \\
\hline 1 & $\begin{array}{l}\text { Need of working overtime and on free } \\
\text { Saturdays }\end{array}$ & 3.99 & 725 & 4 & 306 & 0.989 \\
\hline 2 & Demand for high concentration & 4.23 & 725 & 4 & 366 & 0.530 \\
\hline 3 & Demand for good memory & 3.99 & 725 & 4 & 335 & 0.764 \\
\hline 4 & Demand for solving complicated tasks & 4.15 & 725 & 4 & 310 & 0.739 \\
\hline 5 & $\begin{array}{l}\text { Demand for planning one's actions for } \\
\text { a long time ahead }\end{array}$ & 4.15 & 725 & 4 & 314 & 0.690 \\
\hline 6 & $\begin{array}{l}\text { Demand for making financial decisions } \\
\text { considering one's business }\end{array}$ & 4.21 & 725 & 4 & 328 & 0.647 \\
\hline 7 & Responsibility for the fixed assets & 4.18 & 725 & 5 & 300 & 0.751 \\
\hline 8 & Responsibility for the employees & 4.25 & 724 & 5 & 326 & 0.717 \\
\hline 9 & $\begin{array}{l}\text { Negligence in one's work can lead to } \\
\text { serious consequences }\end{array}$ & 4.29 & 725 & 5 & 351 & 0.682 \\
\hline 10 & $\begin{array}{l}\text { Demand for making fast or (and) risky } \\
\text { decisions }\end{array}$ & 4.06 & 724 & 4 & 300 & 0.772 \\
\hline 11 & Demand for having high qualifications & 3.50 & 724 & 4 & 234 & 1.194 \\
\hline 12 & $\begin{array}{l}\text { Demand for constant learning of new } \\
\text { things }\end{array}$ & 4.12 & 725 & 4 & 329 & 0.727 \\
\hline 13 & Demand for being creative & 4.10 & 725 & 4 & 292 & 0.765 \\
\hline 14 & $\begin{array}{l}\text { Demand for contacting other people } \\
\text { frequently }\end{array}$ & 4.23 & 724 & 5 & 330 & 0.769 \\
\hline 15 & $\begin{array}{l}\text { Demand for cooperating with authorities } \\
\text { and other public institutions }\end{array}$ & 4.17 & 725 & 4 & 298 & 0.734 \\
\hline 16 & $\begin{array}{l}\text { Demand for breaking the rules for the } \\
\text { sake of completing one's tasks }\end{array}$ & 2.76 & 724 & 3 & 233 & 1.366 \\
\hline 17 & $\begin{array}{l}\text { Demand for resolving numerous social } \\
\text { conflicts at the work environment }\end{array}$ & 3.69 & 725 & 4 & 304 & 0.991 \\
\hline
\end{tabular}

Source: own study based on the survey results. 
Table 3. Differentiation of perception of the entrepreneur's psychosocial working conditions (PWP)

\begin{tabular}{|c|c|c|c|c|c|c|c|}
\hline \multirow{2}{*}{$\begin{array}{l}\text { Characte- } \\
\text { ristic's } \\
\text { number }\end{array}$} & \multirow[b]{2}{*}{ Specification } & \multicolumn{6}{|c|}{ Differentiating variable* } \\
\hline & & Gender & Citizenship & University & Grade & $\begin{array}{l}\text { Work } \\
\text { during } \\
\text { studies }\end{array}$ & $\begin{array}{c}\text { General } \\
\text { Experience }\end{array}$ \\
\hline 1 & $\begin{array}{l}\text { Need of working } \\
\text { overtime and on } \\
\text { free Saturdays }\end{array}$ & & 0.0000 & 0.0431 & & 0.0031 & 0.0024 \\
\hline 2 & $\begin{array}{l}\text { Demand for high } \\
\text { concentration }\end{array}$ & 0.0003 & & & & & \\
\hline 3 & $\begin{array}{l}\text { Demand for good } \\
\text { memory }\end{array}$ & 0.0150 & & & & 0.0002 & 0.0000 \\
\hline 4 & $\begin{array}{l}\text { Demand for } \\
\text { solving } \\
\text { complicated tasks }\end{array}$ & 0.0102 & & & & 0.0003 & 0.0001 \\
\hline 5 & $\begin{array}{l}\text { Demand for } \\
\text { planning one's } \\
\text { actions for a long } \\
\text { time ahead }\end{array}$ & 0.0363 & 0.0477 & & & & \\
\hline 6 & $\begin{array}{l}\text { Demand for } \\
\text { making financial } \\
\text { decisions } \\
\text { considering one's } \\
\text { business }\end{array}$ & 0.0001 & 0.0004 & 0.0504 & & 0.0014 & 0.0051 \\
\hline 7 & $\begin{array}{l}\text { Responsibility for } \\
\text { the fixed assets }\end{array}$ & 0.0003 & 0.0037 & & 0.0113 & 0.0273 & \\
\hline 8 & $\begin{array}{l}\text { Responsibility for } \\
\text { the employees }\end{array}$ & 0.0158 & & & 0.0319 & & \\
\hline 9 & $\begin{array}{l}\text { Negligence in } \\
\text { one's work can } \\
\text { lead to serious } \\
\text { consequences }\end{array}$ & & 0.0132 & 0.0111 & 0.0118 & 0.0168 & 0.0351 \\
\hline 10 & $\begin{array}{l}\text { Demand for } \\
\text { making fast or } \\
\text { (and) risky } \\
\text { decisions }\end{array}$ & 0.0008 & & & & & \\
\hline 11 & $\begin{array}{l}\text { Demand for } \\
\text { having high } \\
\text { qualifications }\end{array}$ & 0.0145 & & & & 0.0105 & 0.0312 \\
\hline 12 & $\begin{array}{l}\text { Demand for } \\
\text { constant learning } \\
\text { of new things }\end{array}$ & 0.0005 & & & 0.0328 & 0.0090 & 0.0132 \\
\hline
\end{tabular}


Table 3 (cont.). Differentiation of perception of the entrepreneur's psychosocial working conditions (PWP)

\begin{tabular}{|c|c|c|c|c|c|c|c|}
\hline \multirow[b]{2}{*}{$\begin{array}{l}\text { Characte- } \\
\text { ristic's } \\
\text { number }\end{array}$} & \multirow[b]{2}{*}{ Specification } & \multicolumn{6}{|c|}{ Differentiating variable* } \\
\hline & & Gender & Citizenship & University & Grade & $\begin{array}{l}\text { Work } \\
\text { during } \\
\text { studies }\end{array}$ & $\begin{array}{c}\text { General } \\
\text { Experience }\end{array}$ \\
\hline 13 & $\begin{array}{l}\text { Demand for being } \\
\text { creative }\end{array}$ & 0.0002 & 0.0185 & 0.0330 & 0.0017 & 0.0056 & \\
\hline 14 & $\begin{array}{l}\text { Demand for } \\
\text { contacting other } \\
\text { people frequently }\end{array}$ & & & 0.0007 & 0.0006 & & \\
\hline 15 & $\begin{array}{l}\text { Demand for } \\
\text { cooperating with } \\
\text { authorities and } \\
\text { other public } \\
\text { institutions }\end{array}$ & 0.0009 & & 0.0046 & 0.0161 & 0.0177 & \\
\hline 16 & $\begin{array}{l}\text { Demand for } \\
\text { breaking the rules } \\
\text { for the sake of } \\
\text { completing one's } \\
\text { tasks }\end{array}$ & 0.0008 & 0.0000 & 0.0507 & 0.0014 & & \\
\hline 17 & $\begin{array}{l}\text { Demand for } \\
\text { resolving } \\
\text { numerous social } \\
\text { conflicts at the } \\
\text { work } \\
\text { environment }\end{array}$ & & & & & 0.0084 & 0.0099 \\
\hline
\end{tabular}

* Table does not include variables that do not contribute or insignificantly contribute to the differentiation of the entrepreneur's work perception

Source: own study based on the survey results.

The variable that mostly contributes to the perception of the entrepreneur's work is gender. Women consider that kind of job as connected to the high psychosocial risk statistically crucial differences apply to 13 out of 17 analyzed statements. No differences were noted only for the statements number 1, 9,14 and 17. The students who took up a job while studying at the university evaluated the psychosocial risk connected to 11 characteristics of working as an entrepreneur. No differences were found for statements number $2,5,8,10,14$ and 16 . The variable of studies grade differentiates 8 characteristics. Each of them (items number $7,8,9,12,13,14,15,16)$ got more points from the graduate students (Master's Degree). The assessment of seven characteristics was differentiated by the following variables: citizenship, university and general experience. The influence of working status during the evaluation and the place of residence differentiated the assessment to a very low extent. The former differentiated the assessments of statements 3 and 4 , while the latter - only of the statement number 4 . No statistically significant influence of age and business traditions was noted.

The variable that was considered as the one that could possibly differentiate the entrepreneur's work perception was the academic major. Based on the assessment's results, 
the statistically significant differences were observed only for the assessment of three demands related to the entrepreneur's work: 1, 16 and 14. The statements 1 and 16 were assessed higher by students of Management, whereas the statement 14 was assessed higher by the students of technical studies.

The analysis of the characteristics of the entrepreneur's work according to the adopted variables also indicated those statements in which the greatest variation occurred (Table 4).

Table 4. Characteristics of the entrepreneur's work with the highest number of differentiating variables

\begin{tabular}{|c|l|l|}
\hline $\begin{array}{c}\text { Characteristic's } \\
\text { number }\end{array}$ & \multicolumn{1}{|c|}{ Specification } & \multicolumn{1}{|c|}{ Differentiating variables } \\
\hline 1 & $\begin{array}{l}\text { Need of working overtime and on } \\
\text { free Saturdays }\end{array}$ & $\begin{array}{l}\text { Citizenship, University, major, work } \\
\text { during the studies, general experience }\end{array}$ \\
\hline 4 & $\begin{array}{l}\text { Demand for solving compli- } \\
\text { cated tasks }\end{array}$ & $\begin{array}{l}\text { Gender, place of residence, work during } \\
\text { the studies, general experience, working } \\
\text { status }\end{array}$ \\
\hline 6 & $\begin{array}{l}\text { Demand for making financial } \\
\text { decisions considering one's } \\
\text { business }\end{array}$ & $\begin{array}{l}\text { Gender, citizenship, University, work } \\
\text { during the studies, general experience }\end{array}$ \\
\hline 9 & $\begin{array}{l}\text { Negligence in one's work can } \\
\text { lead to serious consequences }\end{array}$ & $\begin{array}{l}\text { Citizenship, University, grade, work } \\
\text { during the studies, general experience }\end{array}$ \\
\hline 13 & Demand for being creative & $\begin{array}{l}\text { Gender, citizenship, University, grade, } \\
\text { work during the studies }\end{array}$ \\
\hline
\end{tabular}

Source: own study basing on the survey results.

In turn, the assessment of statements 2 and 10 turned out to be differentiated only on the basis of gender, and the statements 5,8 and 17 were differentiated by two variables, respectively: gender and citizenship, gender and degree of study, as well as work during studies and general experience.

The above detailed analysis of the assessment of the entrepreneur's psychosocial working conditions was generalized by creating an index of perception of entrepreneur's psychosocial working conditions (hereinafter referred to as IPWP). It was created by the summing up the points that were assigned by the survey respondents to every statement related to working as an entrepreneur (Babbie, 2007). Its value varies between 17 (when the respondents' answer to all the statements was 1 - strongly disagree) and 85 (when the respondents' answer to all the statements was 5 - strongly agree). Interpretation of scale is intuitive - a higher result means perceiving the entrepreneur's work as being associated with greater psychosocial risk. For the purposes of the interpretation, the following psychosocial risk assessment ranges were created: 17-38 - low psychosocial risk, 39-61 - moderate psychosocial risk, 62-85 - high psychosocial risk. 
Table 5. Index of perception of the entrepreneur's psychosocial working conditions

\begin{tabular}{|c|l|c|c|c|c|}
\hline \multirow{2}{*}{$\begin{array}{c}\text { IPWP point } \\
\text { value }\end{array}$} & Interpretation & \multicolumn{4}{|c|}{ Degree } \\
\cline { 3 - 6 } & & Number & $\begin{array}{c}\text { Cumulative } \\
\text { number }\end{array}$ & Percentage & $\begin{array}{c}\text { Cumulative } \\
\text { percentage }\end{array}$ \\
\hline $17-38$ & Low & 1 & 1 & $0.1 \%$ & $0.1 \%$ \\
\hline $39-61$ & Moderate & 150 & 151 & $20.6 \%$ & $20.8 \%$ \\
\hline $62-85$ & High & 569 & 720 & $78.3 \%$ & $99.0 \%$ \\
\hline shortages & - & 7 & 727 & $1.0 \%$ & $100.0 \%$ \\
\hline
\end{tabular}

Source: own study based on the survey results.

The results show that the respondents consider the entrepreneur's work as connected to high psychosocial risk. In order to check the differentiation level of general assessment of demands connected to the entrepreneur's work determined by the variables listed in Table 1 herein, the U Man Whitney and Kruskal-Wallis tests were conducted (Table 6).

Table 6. Differentiation of perception of the entrepreneur's psychosocial working conditions index

\begin{tabular}{|c|c|c|c|c|c|}
\hline Variable & Category & $\begin{array}{l}\text { Number of } \\
\text { valids }\end{array}$ & $\begin{array}{c}\text { Sum of } \\
\text { ranges }\end{array}$ & $\mathbf{U}$ & Valid Z \\
\hline \multirow{2}{*}{ Gender } & Female & 427 & 164226.00 & \multirow{2}{*}{52263.00} & \multirow{2}{*}{$3.756367 * * *$} \\
\hline & Male & 293 & 95334.00 & & \\
\hline \multirow{2}{*}{ Regular work } & Yes & 284 & 112554.00 & \multirow{2}{*}{51740.00} & \multirow{2}{*}{$3.731630 * * *$} \\
\hline & No & 436 & 147006.00 & & \\
\hline \multirow{2}{*}{$\begin{array}{l}\text { Apprenticeship } \\
\text { and internship }\end{array}$} & Yes & 550 & 203951.00 & \multirow{2}{*}{41074.00} & \multirow{2}{*}{$2.396152 *$} \\
\hline & No & 170 & 55609.00 & & \\
\hline \multirow{2}{*}{$\begin{array}{l}\text { General } \\
\text { experience }\end{array}$} & Bigger & 352 & 136267.00 & \multirow{2}{*}{55397.00} & \multirow{2}{*}{$3.361116 * * *$} \\
\hline & Lower & 368 & 123293.99 & & \\
\hline \multirow{2}{*}{ Grade } & Undergraduate & 321 & 109846.00 & \multirow{2}{*}{58165.00} & \multirow{2}{*}{$-2.118900 *$} \\
\hline & Graduate & 399 & 149714.00 & & \\
\hline
\end{tabular}

$* \mathrm{p}<0.05 ; * * * \mathrm{p}<0.001$

Source: own study based on the survey results.

Among the analyzed variables of the PWP index, some statistically significant differences were found for the following variables: gender, regular work during studies, apprenticeship and internship, general experience. In terms of psychosocial conditions, the entrepreneur's work was assessed as associated with higher demands by: women, people working regularly during studies (regular job, contract of specific work, contract of mandate), people undertaking extra trainings and courses, respondents whose work experience can be evaluated as wide, as well as the Master's level students. The variables that do not differentiate the perception of entrepreneur's work are: citizenship and current employment status (uneven distribution of the variable in both cases), business traditions, major, place of residence and age. 
Based on the survey results, the following entrepreneurial intentions of the respondents were defined: the level of interest in starting a business and the probability of starting a company in two time perspectives: within the next two and five years from the survey (Table 7).

Table 7. The level of interest in starting a business

\begin{tabular}{|l|c|c|c|c|c|}
\hline \multicolumn{1}{|c|}{ Variables $^{5}$} & $\begin{array}{c}\text { Number } \\
\text { of valids }\end{array}$ & Mean & Mode & $\begin{array}{c}\text { Mode } \\
\text { number }\end{array}$ & $\begin{array}{c}\text { Standard } \\
\text { deviation }\end{array}$ \\
\hline Level of interest in starting own business & 725 & 3.80 & 4.00 & 357 & 0.942 \\
\hline $\begin{array}{l}\text { Probability of starting own business within } \\
\text { the next two years }\end{array}$ & 704 & 2.78 & 3.00 & 211 & 1.193 \\
\hline $\begin{array}{l}\text { Probability of starting own business within } \\
\text { the next five years }\end{array}$ & 706 & 3.76 & 4.00 & 315 & 0.920 \\
\hline
\end{tabular}

Source: own study based on the survey results.

Nearly half of the respondents stated that they were "interested" in starting their own business, and 1/5 declared it to a high degree. Such result should be considered good. Entrepreneurial intentions measured by the probability of starting own business are higher in a five-year perspective, though. The cumulative percentage for both "likely" and "very likely" responses for the two-year perspective is $27 \%$, and for the five-year perspective nearly $64 \%$. The study of the relationship between entrepreneurial intentions and the psychosocial working conditions index (IPWP) using Pearson's correlation coefficient is presented in Table 8.

Table 8. Value of the Pearson's correlation coefficient (Pearson's $r$ ) between the psychosocial working conditions index (IPWP) and the entrepreneurial intentions

\begin{tabular}{|l|c|c|}
\hline \multicolumn{1}{|c|}{ Variable } & Pearson's $\boldsymbol{r}$ & p \\
\hline Level of interest in starting own business & 0.091932 & $<0.05$ \\
\hline Probability of starting own business within the next two years & 0.050814 & n.m. \\
\hline Probability of starting own business within the next five years & 0.100677 & $<0.05$ \\
\hline
\end{tabular}

Source: own study based on the survey results.

The obtained results show the existence of indistinct (very weak) yet statistically significant correlations between the IPWP and the level of interest in starting own business and the probability of starting own business within five years. There is no connection between the IPWP and probability of starting own business within the next two years (correlation is very weak and not statistically significant $)^{6}$.

\footnotetext{
${ }^{5}$ All of the variables were evaluated using the Likert scale. In case of the first statement - the respondents were stating one's own interest in starting own business from 5 - very interested to 1 - not interested. In case of the probability: from 5 - very likely to 1 - not likely.

6 The power of linear dependence was interpreted with use of the following scale: $=<0.2$ weak correlation, $>0.2-=<0.4$ clear but weak correlation, $>0.4-=<0.6$ moderate, $>0.6-=<0.8$ significant, $>0.8$ ideal and very strong correlation (Kowal 2011).
} 


\section{DISCUSSION OF RESULTS AND CONCLUSIONS}

Summing up the obtained results, it should be stated that the entrepreneur's work is perceived by students as burdened with high psychosocial risk, requiring constant attention and concentration, combining high responsibility for decisions both in the financial and human-related terms. Such picture concerns both the specific work characteristics (13) and the IPWP Index created on their basis. However, it is not homogeneous. The variable that differentiates the perception of the entrepreneur's work to the highest extent is gender ${ }^{7}$. Women assess this type of work as more stress-causing. It seems that this variable could be important both in the biological aspect (sex) and sociocultural one (gender), which is connected with socialization and functioning stereotypes in a certain society (Mandal, 2003; Królikowska, 2011). "Therefore it should be considered not as a straight bipartite demographic variable, but as a wide and hard to define context and social construct, considered both as an individual aspect and cultural one" (Mandal, 2003). In this respect, it is certainly worth undertaking further research and in-depth analysis.

Another important variable differentiating the perception of the entrepreneur's work at the level of some specific characteristics (11) and the IPWP was regular work during studies. The respondents who used to work or were working regularly when taking part in the survey perceived the entrepreneur's work as associated with a greater psychosocial risk. It should be assumed that in the course of their professional career they had had the opportunity to observe the work of entrepreneurs and stressors that they had encountered, which made the picture more realistic. This interpretation is also supported by the perception of the entrepreneur's work as more stress-causing by the Master's level students ( 8 characteristics, IPWP) and with more professional experience ( 7 characteristics, IPWP). What is surprising, however, the current status of employment turned out to be the only variable that minimally differentiated the perception of the entrepreneur's work ( 2 characteristics). This certain inconsistency is most likely due to the fact that some respondents who declared working during their studies may not be working currently (e.g. due to resignation from work in order to focus on the preparation of the diploma thesis). Therefore, each respondent assigned to the same group can significantly differ from other ones. Surprisingly, the traditions of entrepreneurship in the family do not differentiate the perception of the entrepreneur's work. This in turn may result from the overall high assessment of the requirements related to the work of the entrepreneur. Similarly, age does not differentiate the perception of the entrepreneur's work. It seems that this is related to the relatively small diversity of respondents as all of them de facto belong to one cohort. In addition, studies conducted among managers indicate that age is not a variable that differentiates the level of the experienced stress (Jabłkowska, Borkowska, 2005).

The field of study (major) slightly differentiated the perception of the entrepreneur's work ( 3 characteristics). However, it should be noted that the students of technical faculties assessed the statement "Demand for contacting other people frequently" higher than other respondents. This difference may result from the fact that the Management studies attach greater importance to the education of the so-called soft skills, as well as differences in the perception of the desired work environment ("work with machines" - "work with people") at the stage of choosing the field of study.

\footnotetext{
${ }^{7}$ Also in the studies of K. Jabłkowska and A. Borkowska related to the elevated stress level at work and the professional burnout it turned out that gender was a differentiating factor of experienced stress level (Jabłkowska, Borkowska, 2005).
} 
The university is a variable that differentiated the perception of the entrepreneur's work with respect to its 7 characteristics. However, they are difficult to interpret unequivocally due to differences in sample sizes within individual universities and due to the diversity of respondents from the Lublin University of Technology - the respondents came from two different fields of study - Management and technical studies. Thus, the variable "field of study" seems more reliable and easier to interpret. It should be noted, however, that the students from the Technical University obtained the highest result in relation to the statement "Demand for contacting other people frequently", which is in line with the differences observed with respect to the variable "field of study".

A unique feature of the Lublin educational market is the growing presence of students from across the eastern border. Among the respondents there were 48 respondents who had citizenship other than Polish. Due to the high disproportion between the number of students with Polish and other citizenship, one should beware of far-reaching caution in formulating conclusions. However, it is worth considering the differences observed. It seems that they should be interpreted with regard to the cultural differences, different experiences related to the observation of the entrepreneurs and the socio-economic and legal environment in the country of origin. This applies, inter alia, to statement 16 ("Demand for breaking the rules for the sake of completing one's tasks"), where a higher score was given by the foreign students.

The last of the analyzed variables, i.e. the place of residence, did not differentiate the perception of the psychosocial working conditions of the entrepreneur neither in relation to the entire index, nor some specific characteristic. As the respondents are the students of the last year of both undergraduate and graduate studies, it seems likely that any differences could be lost due to several years of living in the same environment.

The practical aim of the research presented herein is to identify the factors that have positive impact on the entrepreneurial intentions. However, the analyzes carried out do not indicate a relationship between the assessment of the psychosocial working conditions and the entrepreneurial intentions (statistically significant correlations at the level of 0.1 in case of general interest in running their own business and starting it within five years). This may lead to the conclusion that the respondents at the current stage of career planning do not consider this factor. This can be explained by the relatively small professional experience of students of general academic courses. Although almost half of the respondents (49\%) were qualified to a group with a high level of professional experience due to the continuous work during their studies (including work in a family business), only 12 respondents had their own experience in running a business. The age of the respondents may also have considerable impact on the results, as it is more connected with the focus on values such as leadership and taking up challenges than security or stabilization (Lubrańska, 2016).

The obtained results show possible ideas for further and more in-depth research. This applies not only to deepening the research on identifying the reasons for differentiating the assessment of the psychosocial working conditions of the entrepreneur, but above all the confrontation with how entrepreneurs assess their work in this area. Only then will it be possible to indicate the directions of possible actions that could favor the entrepreneurial attitudes of students. 


\section{REFERENCES}

Arent, A., Walczyna, A. (2014a). Środowisko uczelni a postawy przedsiębiorcze studentów wyniki badań pilotażowych. „Organizacja i Zarzadzanie. Kwartalnik Naukowy” 3(27).

(2014b). Przedsiębiorczość studentów - wyniki badań pilotażowych [w:] Bojar, E., Żminda, T., Bis, J., red., Region i edukacja a procesy rozwojowe. Lublin: Wyd. Politechniki Lubelskiej.

- (2018). Wybrane cechy demograficzne $i$ indywidualne a intencje przedsiębiorcze studentów. „Zeszyty Naukowe Politechniki Ślaskiej Seria: Organizacja i Zarzadzanie” 132.

Babbie, E. (2007). Badania społeczne w praktyce. Warszawa: Wydawnictwo Naukowe PWN.

Barba-Sánchez, V., Atienza-Sahuquillo, C. (2017). Entrepreneurial motivation and selfemployment: evidence from expectancy theory. "International Entrepreneurship and Management Journal” 13(4).

Basińska, B. (2005). Warunki pracy a źródła stresu właścicieli małych przedsiębiorstw [w:] Walczak-Duraj, D., red., Humanizacja wobec wyzwań transformacyjnych i cywilizacyjnych. Płock: Wydawnictwo Naukowe Novum.

Biegańska, K. (2008). Uciążliwość i psychologiczne koszty pracy. Negatywne aspekty funkcjonowania w roli wtaściciela firmy. „Acta Universitatis Lodziensis. Folia Psychologia” 12. Cieślak, R., Widerszal-Bazyl, M. (2000). Psychospoteczne warunki pracy. Podręcznik do kwestionariusza. Warszawa: CIOP-PIB.

Cox, T., Griffiths, A., Rial-Gonzalez, E. (2006). Badania nad stresem zwiazanym z praca. Belgia: Europejska Agencja Bezpieczeństwa i Zdrowia w Pracy.

Derbis, R., Baka, Ł. (2011). Znaczenie wsparcia społecznego i zaangażowania $w$ prace dla zwiąku stresorów w pracy i wypalenia zawodowego. „Czasopismo Psychologiczne” 17(2).

Dudek, B., Waszkowska, M., Merecz, D., Hanke, W. (2004). Ochrona zdrowia pracowników przed skutkami stresu zawodowego. Łódź: Instytut Medycyny pracy im. Prof. J. Nofera.

Fila, M.J. (2016). The job demands, control, support model: Where are we now?. "International Journal for Research in Management" 1(1).

Gasse, Y., Tremblay, M. (2011). Entrepreneurial Beliefs and Intentions: A Cross-Cultural Study of University Students in Seven Countries. "International Journal of Business" 16(4).

Hassard, J., Teoh, K.R.H., Visockaite, G., Dewe, P., Cox, T. (2018). The cost of work - related stress to society: A systematic review. "Journal of Occupational Health Psychology" 23(1). DOI: 10.1037/ocp0000069.

Jabłkowska, K., Borkowska, A. (2005). Ocena nasilenia stresu w pracy a cechy zespołu wypalenia zawodowego u menedżerów. „Medycyna Pracy” 56(6).

Kaczmarska, A., Curyło-Sikora, P. (2016). Problematyka stresu - przeglad koncepcji. „Hygeia Public Heath" 51(4).

Kowal, J. (2011). Statystyka opisowa w zarzadzaniu [w:] Knecht, Z., red., Zarzadzanie przedsiębiorcze. Wrocław: WSZE.

Królikowska, S. (2011). Nierówności w stanie zdrowia między kobietami a mężczyznami w kontekście ptci biologicznej oraz spoteczno-kulturowej. „Acta Universitatis Lodziensis. Folia Sociologika” 39.

Krueger, N.F., Reilly, M.D., Carsrud, A.L. (2000). Competing models of entrepreneurial intentions. "Journal of Business Venturing” 15.

Leka, S., Griffiths, A., Cox, T. (2003). Work Organization \& Stress. Warszawa: CIOP-PIB. 
Liñán, F., Fayolle, A. (2015). A systematic literature review on entrepreneurial intentions: citation, thematic analyses, and research agenda. "International Entrepreneurship and Management Journal" 11(4).

Lubrańska, A. (2016). Wartości cenione w pracy zawodowej - różnice międzypokoleniowe. „Zarządzanie Zasobami Ludzkimi” 3-4 (110-111).

Lüthje, Ch., Franke, N. (2004). Entrepreneurial Intentions of Business Students: A Benchmarking Study. "International Journal of Innovation and Technology Management" 1(3).

Mandal, E. (2003). Kobiecość i męskość - popularne opinie a badania naukowe. Warszawa: Wydawnictwo Akademickie ,ŻAK”.

Mills, C.E., Pawson, K. (2006). Enterprising talk: a case of self construction. "International Journal of Entrepreneurial Behaviour \& Research” 12(6).

Mockałło, Z., Widerszal-Bazyl, M. (2018). Ocena wymagań jako wyzwań i przeszkód w pracy $i$ jej wptyw na efektywność $i$ dobrostan pracowników. „Bezpieczeństwo Pracy. Nauka i Praktyka” 10(565).

Mościcka-Teske, A., Potocka, A. (2014). Skala Ryzyka Psychospołecznego. Budowa i zasady stosowania. Gdańsk: Komisja Krajowa NSZZ „Solidarność”.

- (2016). Zagrożenia psychospoteczne $w$ miejscu pracy w Polsce. „Zeszyty Naukowe Politechniki Poznańskiej. Organizacja i Zarządzanie” 70. DOI: 10.21008/j.0239-9415. 2016.070.10.

Orlak, K., Gołuch, D., Chmielewski, J. (2014). Stres w pracy oraz jego wptyw na występowanie wypadków przy pracy $i$ stan zdrowia osób pracujacych. Warszawa: Stowarzyszenie Zdrowa Praca.

Piróg, D. (2014). Uwarunkowania przedsiębiorczości absolwentów szkót wyższych: założenia teoretyczne i stan rzeczywisty. „Przedsiębiorczość i Edukacja” 10.

Potocka, A. (2012). Narzędzia kwestionariuszowe stosowane $w$ diagnozie psychospołecznych zagrożeń zawodowych - przeglad metod. „Medycyna Pracy” 63(2).

Potocka, A., Waszkowska, M. (2013). Zastosowanie modelu „Wymagania pracy - zasoby” do badania zwiazku między satysfakcja zawodowa, zasobami pracy, zasobami osobistymi pracowników i wymaganiami pracy. „Medycyna Pracy” 64(2).

Schaufeli, W.B., Taris, T.W. (2014). A Critical Review of the Job Demands-Resources Model: Implication forImproving Work and Health [In:] Bauer, G.F., Hämmig, O., ed., Bridging Occupational, Organizational and Public Health. A Transdisciplinary, Springer.

Sieger, P., Fueglistaller, U., Zellweger, T. (2011). Entrepreneurial Intentions and Activities of Students across the World. Swiss: University of St. Gallen.

Solesvik, M.Z. (2013). Entrepreneurial motivations and intentions: investigating the role of education major. "Education + Training" 55(3).

Syper-Jędrzejak, M. (2014). Strategie radzenia sobie ze stresem w pracy menedżera. „Humanizacja Pracy” 4(278).

Walczyna, A., Arent, A., (2014). Stresogenność pracy przedsiębiorcy w ocenie studentów wyniki badań pilotażowych. „Modern Management Review” 4(XIX). DOI: 10.7862/rz. 2014.mmr.60.

Widerszal-Bazyl M. (2009). Pojęcie ryzyka psychospołecznego w pracy. „Bezpieczeństwo Pracy” 06(423).

(2017). Kopenhaski Kwestionariusz Psychospoteczny (COPSOQ) - wtaściwości psychometryczne wybranych skal w polskiej wersji. „Medycyna Pracy” 68(3). DOI: 10.13075/mp. 5893.00443. 
Wróblewska, V. (2013). Źródła stresu w pracy zawodowej menedżerów. „Zeszyty Naukowe Uniwersytetu Przyrodniczo-Humanistycznego w Siedlcach” 25(98).

CIOP-PIB, (2009). Zarzadzanie ryzykiem psychospołecznym - ramowe podejście europejskie. Wskazania dla pracodawców i reprezentantów pracowników. Warszawa: CIOP-PIB.

Żemigała, M. (2007). Czynniki stresu w zarzadzaniu firma. „Bezpieczeństwo Pracy. Nauka i Praktyka” 3(426).

DOI: 10.7862/rz.2020.hss.24

The text was submitted to the editorial office: August 2019.

The text was accepted for publication: June 2020. 
